University of Nebraska - Lincoln

DigitalCommons@University of Nebraska - Lincoln

Textile Society of America Symposium

Proceedings

Textile Society of America

2020

The yuraq haku, or plain mantle: A long tradition of north-central

Perú

María Elena del Solar

Crestina Jara

Follow this and additional works at: https://digitalcommons.unl.edu/tsaconf

Digitalrt of the Art and Materials Conservation Commons, Art Practice Commons, Fashion Design

Commens, Fiber, Textile, and Weaving Arts Commons, Fine Arts Commons, and the Museum Studies

detwerkns

Logo

This Article is brought to you for free and open access by the Textile Society of America at

DigitalCommons@University of Nebraska - Lincoln. It has been accepted for inclusion in Textile Society of America

Symposium Proceedings by an authorized administrator of DigitalCommons@University of Nebraska - Lincoln. 


\title{
The yuraq haku, or plain mantle: A long tradition of north-central Perú
}

\author{
María Elena del Solar \& Crestina Jara \\ mariaelenadelsolar@gmail.com
}

Studies on the textile industry in Panao by Emilio Mendizábal (1990) ${ }^{1}$ and Emilio Mendizábal and Richard Bird $(1998)^{2}$, show that little has changed in the tradition of textile production in the region, which is nowadays focused on identifying new spaces for marketing among the public that participates in local festivities and possible contacts with Lima. The attraction of the cities has encouraged the displacement of weaving families to the district capital, who also seek the benefit of a better education for their children and a better positioning of rural production in the market, a widespread phenomenon in rural areas in recent decades.

This is a contemporary story that takes a new look at an old theme by developing a collaborative ethnography achieved through the adaptation to socially distanced research practices. The review of La Visita de la Provincia de León de Huanuco in $1562^{3}$ constitutes a first-rate source for approaching the important presence of the cotton resource and textile production in the tributary economy of the early colony, which we intend to explore in greater depth in a subsequent publication.

The master spinner and weaver Crestina Jara (Fig. 1), a bilingual Quechua-Spanish speaker, like the vast majority of the population of the area, born in the Panao region and now a married resident of the village of Tambogán, has made this experience possible, otherwise impossible due to the restrictions we are experiencing during the pandemic. The previously planned field visit had to be exchanged for long and open telephone conversations, which led to gestures of mutual confidence, as well as her own initiatives which enriched the contents of the study with greatly inspiring results. Crestina has represented her universe spontaneously and in graphic form, enriching the human dimension of the study and, in this way, complementing an especially significant narrative by making visible the life of a mountain community as well as the contemporary situation of the weavings of her village. ${ }^{4}$

\footnotetext{
${ }^{1}$ Emilio Mendizábal L., Continuidad Cultural y Textilaria en Pachitea Andina, (Lima: Tarea, 1990).

${ }^{2}$ Robert McKelvy Bird and Emilio Mendizábal L., "Textiles, Weaving, and Ethnic Groups of Highland Huanuco, Peru," In The Junius B. Bird Conference On Andean Textiles. A.P. Rowe Editor, (Washington, D.C.: The Textile Museum, 1986), 339-361.

${ }^{3}$ Iñigo Ortiz de Zúñiga, Visita de la Provincia de Leon de Huanuco en 1562, Tomo I. J. Murra Editor. (Huánuco: Universidad Nacional Hermilio Valdizán, 1967), Tomo II. J.Murra Editor. (Huánuco: Universidad Nacional Hermilio Valdizán, 1972).

${ }^{4}$ The visual dialogue undertaken by Crestina Jara, with the help of her daughter, spontaneously produced a set of images depicting the family's domestic life, the geographical environment, the daily walk to the farm, the products of the fields and in particular the weaving activities and the various ways of wearing the white mantle. Unfortunately, due to space limitations, we present only a few of them.
} 


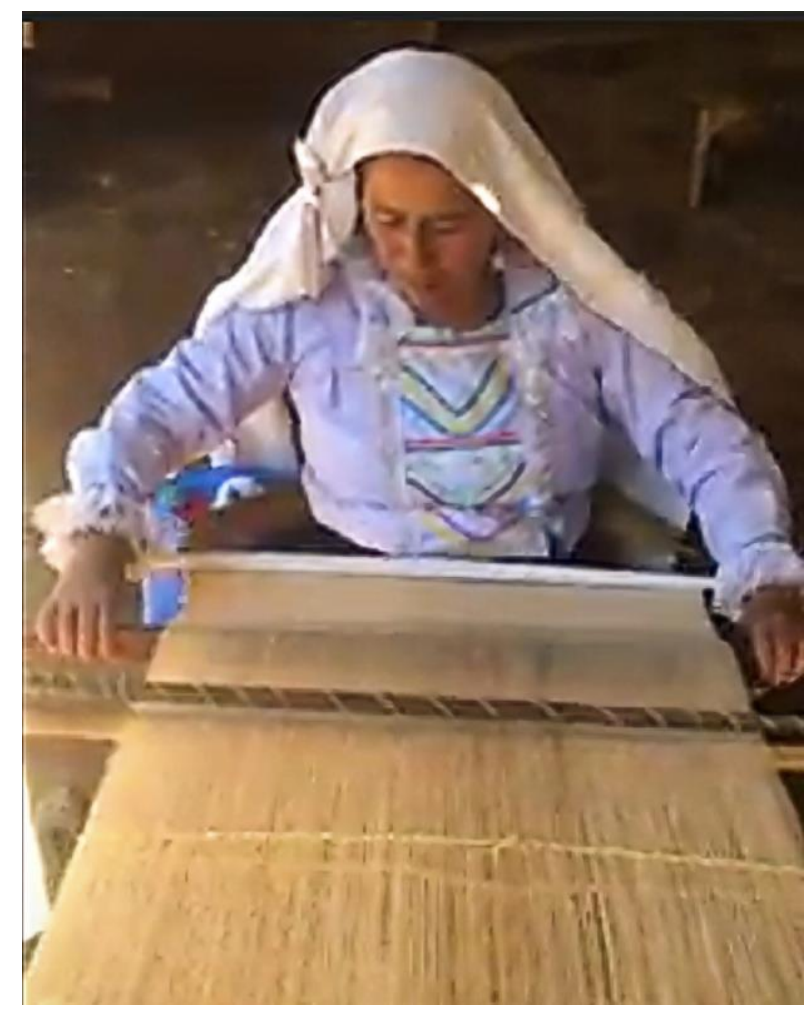

Figure 1. Weaver Crestina Jara. Age 47, 4 children.

We would like to emphasize that all the images that follow are Crestina's, as well as the ethnographic information contained therein, unless otherwise indicated. Insofar as it was not possible for me to carry out the fieldwork in person, it is important to highlight the agency shown by Crestina Jara to get involved in the focus of the study, contributing to the experience in a new collaborative way of developing a remote ethnography, which has perhaps emerged to stay with us for some time (Fig. 2).

a)

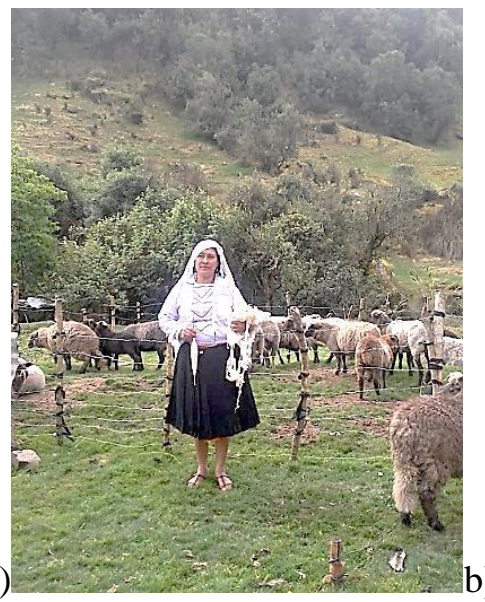

Figure 2. $a$, b) Crestina Jara with her livestock and in her flowering potato field. c) Tree tomatoes

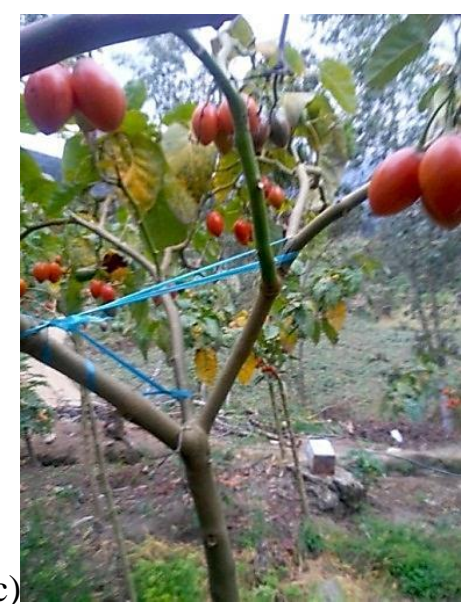

(tomates "España") from her orchard. 


\section{Contexts: the weaver and her mantles}

The yuraq haku (q.) or white mantle is a garment characteristic of the districts of Churubamba and Panao, department of Huánuco, to the north-east of Lima (Fig. 3), which maintains its predominance and frequent use in the rural sphere, as well as in official representations of local culture, both within and outside the region. It is woven on a back-strap loom, with hand-spun native cotton, and has a quadrangular shape composed of two woven panels of four selvedges each. It is impossible to find similarities to its range of characteristics, in the fineness of the yarn and the delicacy and balance of its weave, among known contemporary Peruvian textiles. At once austere and sophisticated, its plain design carries no decoration except for a delicate edging of brightly colored yarn on its border.

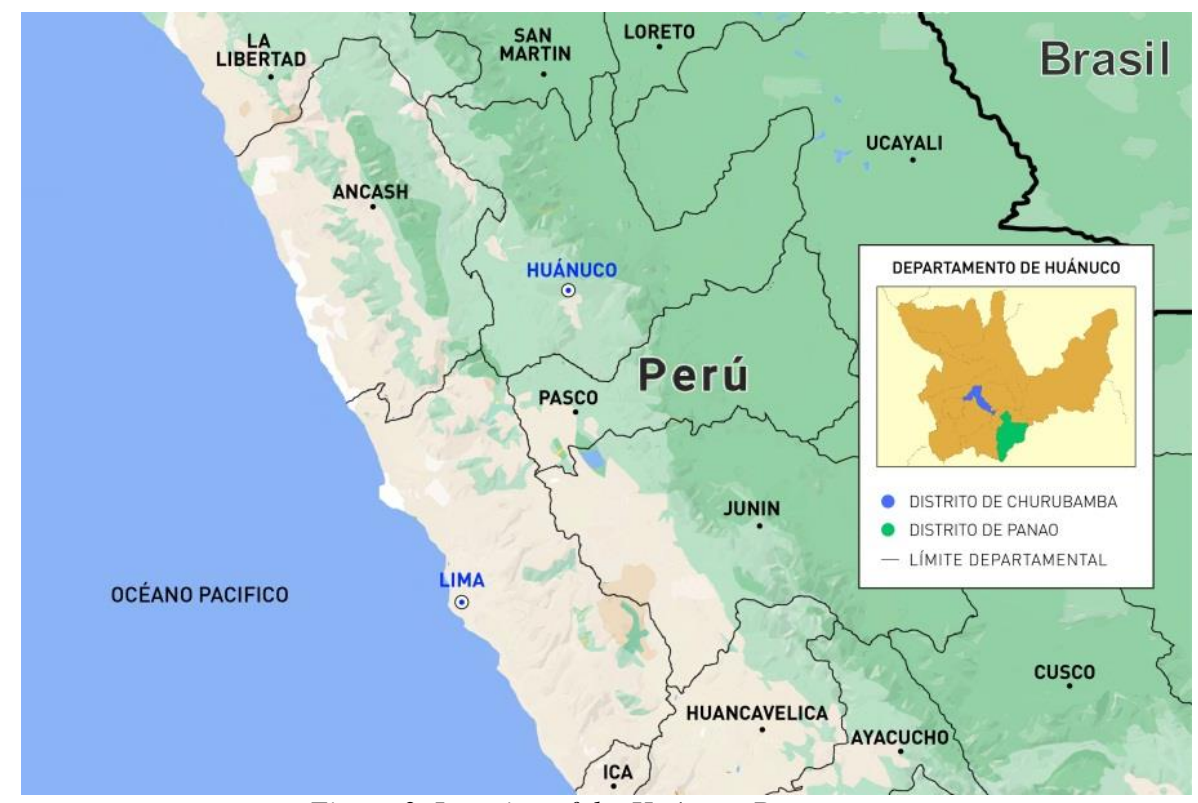

Figure 3. Location of the Huánuco Department.

These modest plain weave mantles, without structural complexity, I regretfully must say have little interest for conventional museum exhibition due to the absence of color and pattern, although they are the bearers of an important diagnostic material tradition. To consider them today implies taking into account diverse sociocultural contexts that have occurred over time. ${ }^{5}$

The traditional textile technology of the backstrap loom, hakun away (q.), for the production of four-edged weavings is still widely used. ${ }^{6}$ The pride of a good weaver is represented in the texture and exceptional transparency of a fine mantle to wear, achieved through the delicacy of its handspun yarns and the precise balanced spacing of the weft yarns. (Fig. 4a)

\footnotetext{
${ }^{5}$ The incorporation of data from the comparative archaeological or historical material recovered is pending a forthcoming visit to the area.

${ }^{6}$ As does the pedal loom for weaving bayeta cloth for garments, though it is not the topic of this study.
} 
a)

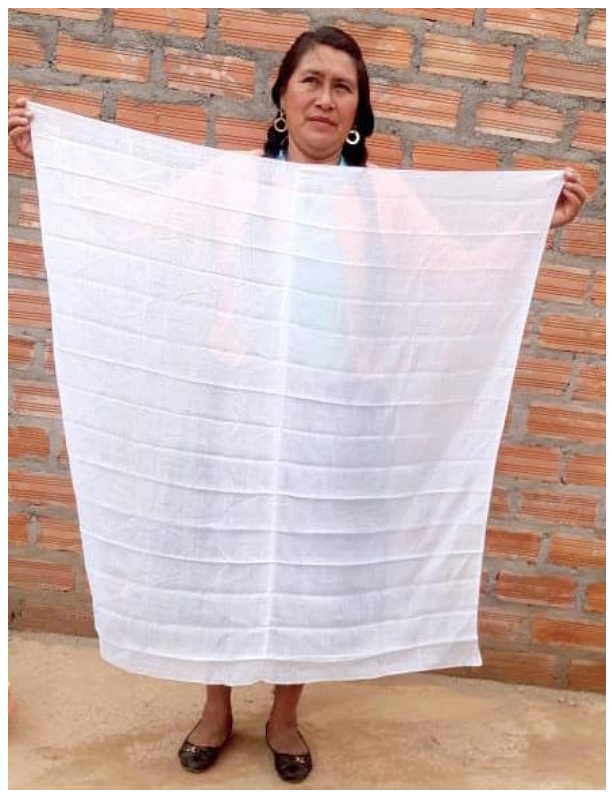

b)

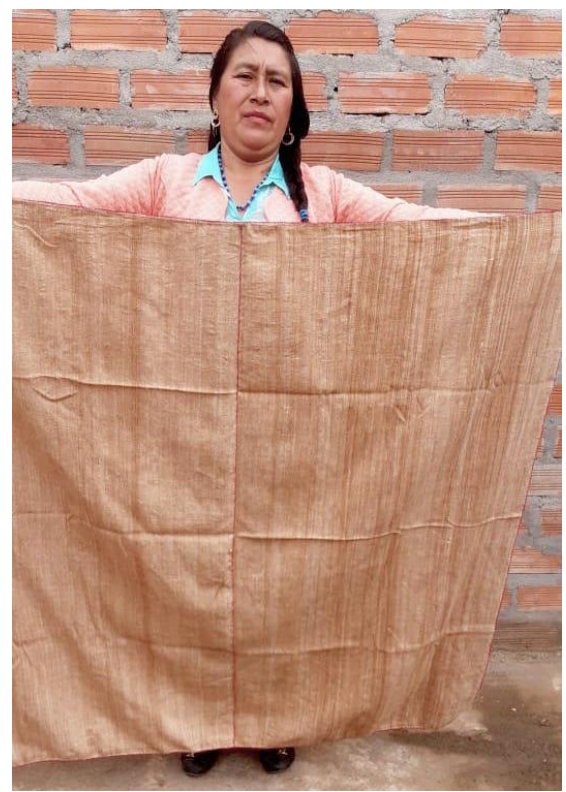

Figure 4. a) The yuraq haku white mantle, hand woven in cotton. b) Mantle for carrying a burden, woven in native colored cotton, oge (local). Both in back strap loom, plain weave. Two pieces, seamed.

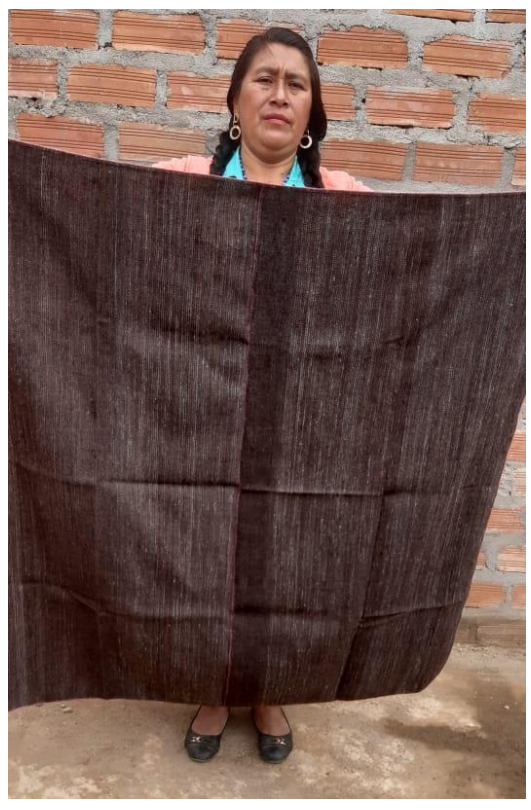

b)

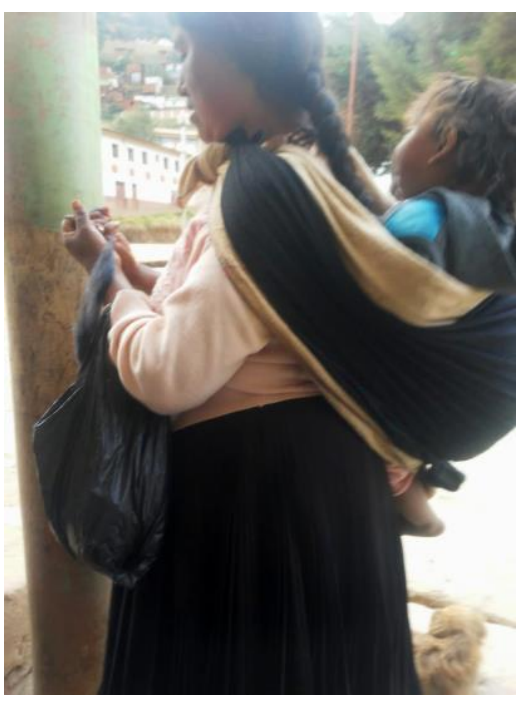

Figure 5. a,b).Qualities of thickness and torsion of the yarns are referred to the use and function of the mantles: to show the weaver's ability and elegance, for warmth or for heavy loads. In the photo two mantles in sheep wool.

Not only cotton mantles are woven in Churubamba and Panao, but also very fine haku are woven in sheep's wool (Fig. 5). The introduction of sheep with Spanish colonization implied contact with a fiber of a very different quality and texture to cotton. The adaptation to the new materials and techniques brought from Spain was possible on the basis of the great technical knowledge and levels of specialization of both men and women, the Andean spinners and weavers. It is also common to find a combination of both materials in fine mantles, where the choice of cotton or wool for the warp, or shayana (q.), and the weft, or miñin (q.), is usually indifferent. 


\section{Native cotton, áspero or 'rough' variety}

Cotton, $u t k u(q$.$) , is the most abundant textile resource in the area and is considered the preferred$ raw material for traditional weaving. It is found in the inter-Andean and subtropical montane forest in the upper rainforest regions towards the east, along the course of the Huallaga river and its highland tributaries. (Fig. 6) It belongs to the species Gossypium barbadense L., 'áspero' variety, which is grown semi-wild or perennial form along the edges of cultivated fields and as hedgerows in the north coastal regions, or planted in small areas associated with cultivation of domesticated manioc, pineapple, papaya and cacao, in the Amazonian regions.

The earliest evidence of cotton's domestication has been excavated in the Nanchoc valley (ca. $7800 \mathrm{cal}$ BP) on the upper Zaña valley in northern Peru ${ }^{7}$. A number of scholars have argued that cotton was managed and propagated first in the Amazon Basin, home of its wilder varieties, and from there taken to the yungas regions of the Pacific watersheds (and thereby domesticated). On the coast it is currently produced in up to eight shades; in the high jungle and in the Amazonia region it is found in white, $\operatorname{yuraq}(q$.), and in two shades of brown, oqe (q.).

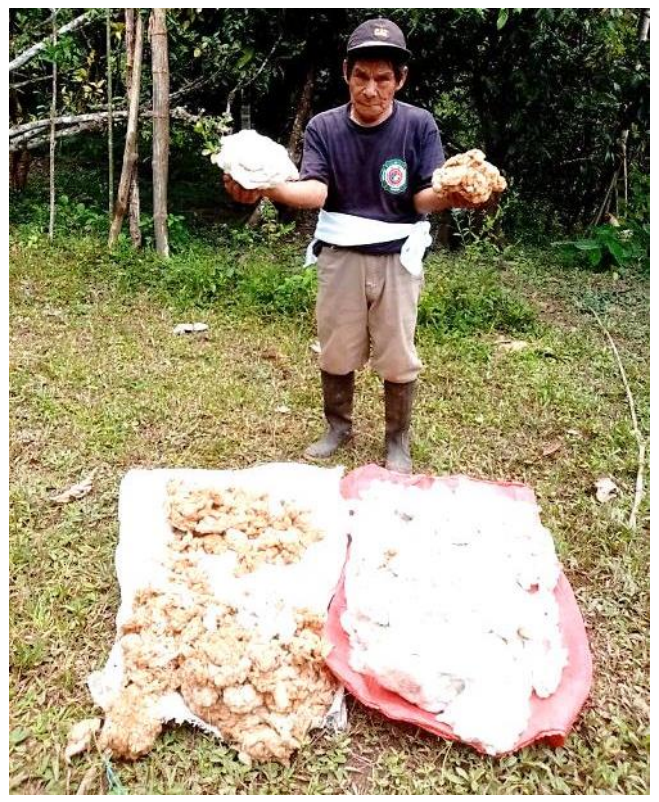

Figure 6. Juan Jara wears the white mantle as a belt, wachka haku(q.), photographed by his niece Crestina on his farm in Chunatawa. Panao district. 2020.

Crestina Jara explains that she must travel to the rainforest in order to obtain the best quality, which is bought in the low lands, 'bajera', in Chullki, Matara, Playa roja, Monzón. In addition to its use for textiles, balls of raw cotton are often used as a home remedy for the treatment of topical and somatic ailments.

7 J. C. Splitstoser, T. D. Dillehay, J. Wouters, and A. Claro, "Early pre-Hispanic use of indigo blue in Peru," Science Advances (14 Sep 2016); Vol. 2, no. 9, e1501623 DOI: 10.1126/sciadv.1501623. 


\section{An exceptional yarn}

The production of yarn with the spindle, $p^{\prime} u c h k a$ (q.), is one of the main specialized jobs in the textile production chain that is maintained to this day among Andean communities and on whose care depends the final quality of the woven garment. This work begins with the initial tasks of selection and cleaning of the raw material (cotton or wool). An astonishing firmness, uniformity and precision is achieved in the yarn -usually of a single strand- used to make the delicate fine yuraq haku.

The twisting of the thread is generally $\mathrm{Z}$, manaycuy (q.), and the plying done in $\mathrm{S}$, ichoq (q.). However, spinners today indicate that they also know how to spin in $S$, and that their grandmothers likewise spun in $\mathrm{S}$. The direction indicated would be to achieve "a more resistant cloth". I wonder if this "resistance" might be referring to a personal emotional strength to resist the dark arts of the shamans. ${ }^{8}$

Today we see a refined differentiation in the treatment of the materials, cotton and wool, in the preparation techniques, as well as the size and weight of the spindles. For example, Crestina notes that "you don't spin cotton in the breeze or in the cold, because it will stick or break", or, "it is different what I need to spin while sitting or standing, walking", in reference to the tool, the material and the desired texture.

a)

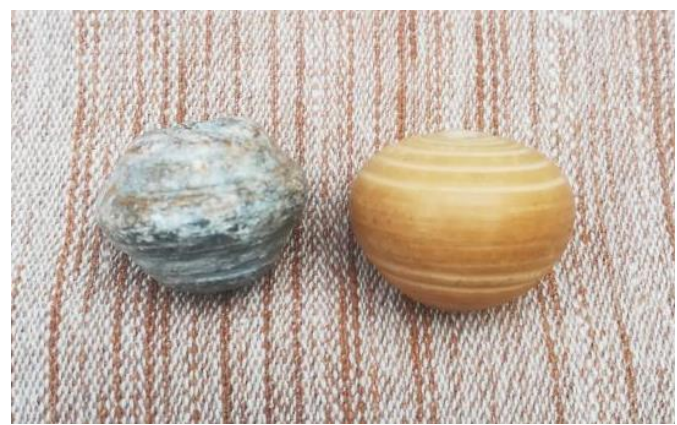

b)

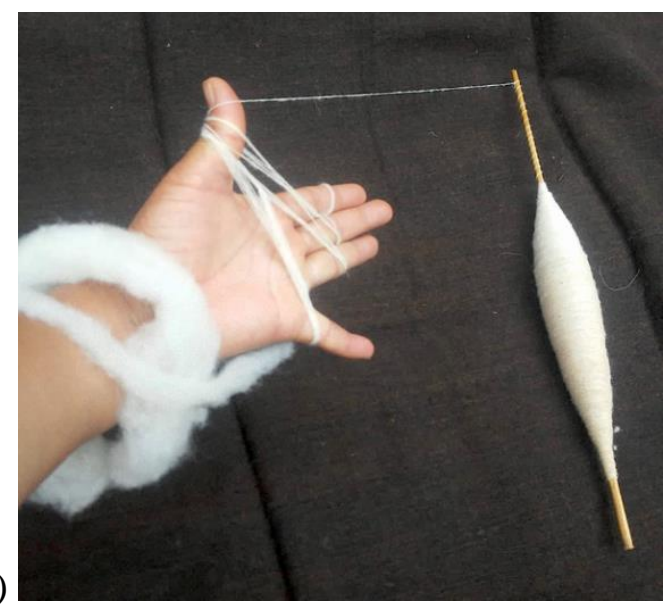

Figure 7 a) Spindle flywheels made of limestone and of tawa (q.), an Amazonian seed). b) Cotton fiber and yarn

The spindle whorl we see on the left above is made by each weaver, of limestone, and its roundness and polish is achieved by turning the piece within a hole in the earth. This has more weight and is appropriate for sheep's wool with a drop spindle. The lighter one to the right is for cotton spun in a seated position. It is made of tawa (q.), a seed of the aguaje palm that grows in the lowlands to the east, in the same ecozone where cotton is planted. (Fig. 7)

\footnotetext{
${ }^{8}$ The thread twisted in an S direction is used in traditional medicine as protection against bewitchment and harm, especially in the southern Andes. It is common to use a cord tied around the wrist of newborns to prevent the "evil eye".
} 

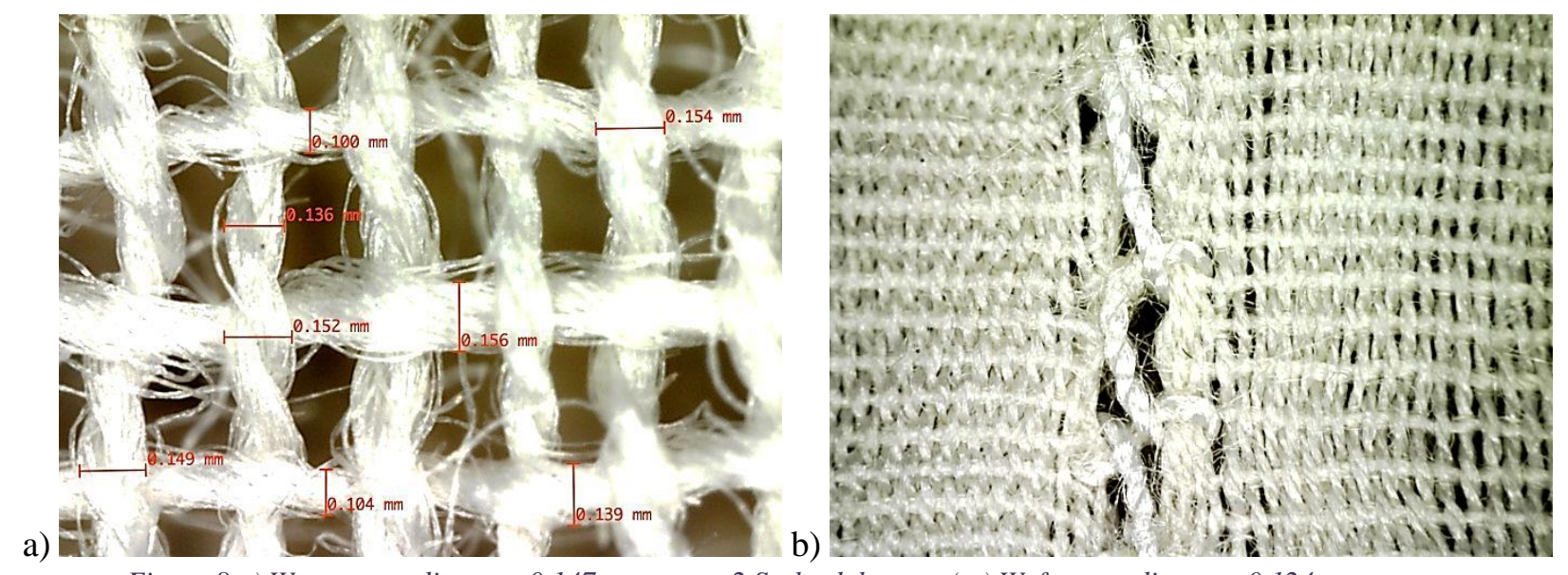

Figure 8 a) Warp yarns diameter $0.147 \mathrm{~mm}$ z-spun 2 S-plyed, kaupuy (q.) Weft yarns diameter 0.124mm z-spun.

b) Two pieces, callu (q.), sewn together form the quadrangular mantle. Average density of the cloth.

31 warp yarns per cm / 25 weft yarns per cm. Photos: S. Desrosiers.

In the macro photo (Fig. 8) we can clearly observe the two-ply warps, kaupuy (q.), and the single-ply weft in a fine cotton mantle. Also, the diameter of the yarns, which correspond approximately to a tenth of a millimeter, as well as the fantastic natural sheen of the cotton. We next see the seam joining the two callu (q.), as well as a greater density of the warps in relationship to that of the wefts. An average relationship, based on sampling three points in the same mantle, is 31 warp yarns by 25 weft yarns per centimeter.
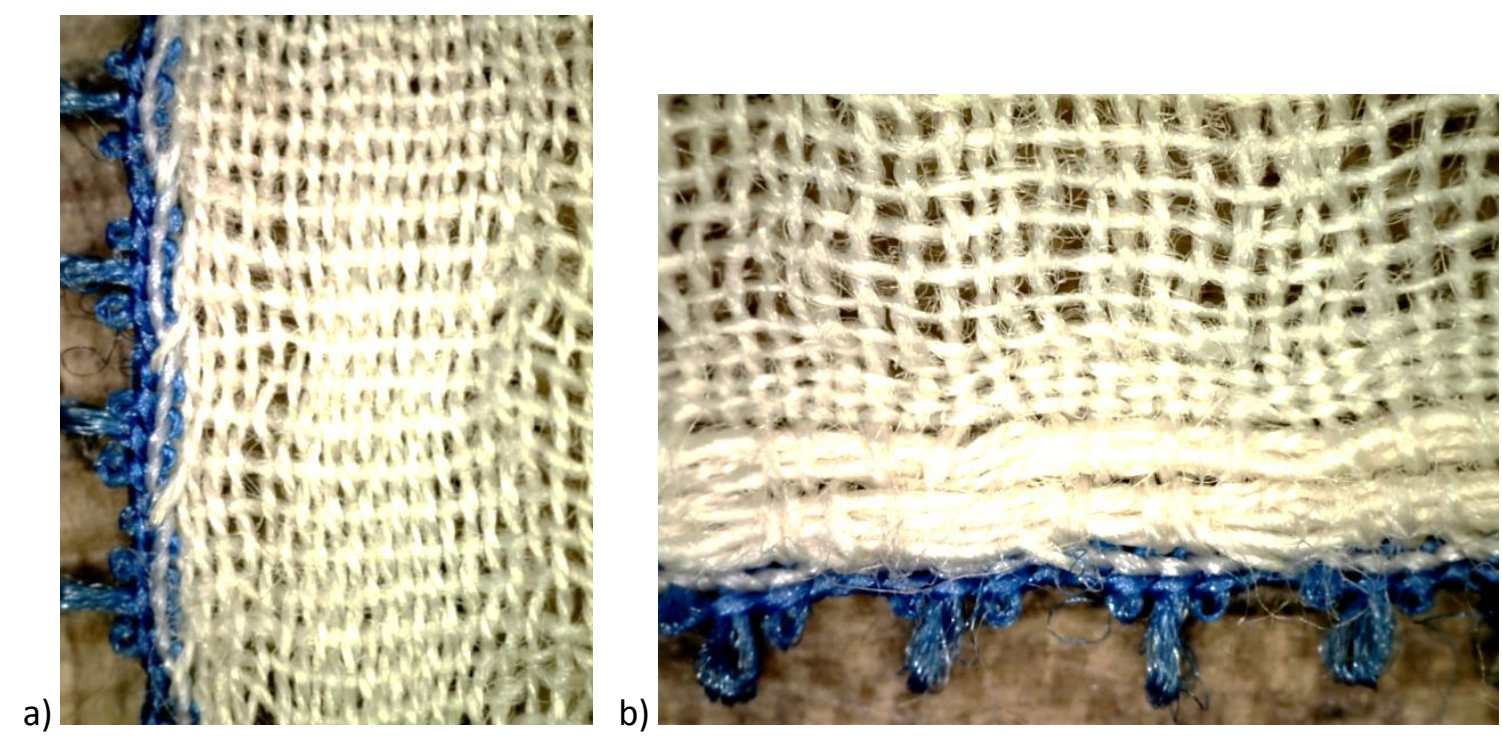

Figure 9. Edge finishes. a) Weft-turn selvedge border. b) Warp-end selvedge border. Photo, S. Desrosiers. 


\section{Diversity of uses and ways of tying the mantle}

In their studies on Panao textiles, Mendizabal and Bird (1986) and Mendizabal (1990) record more than 15 different ways of carrying the mantle. The diversity of ways involves not only gender, but also the age group and the specific activity being carried out.
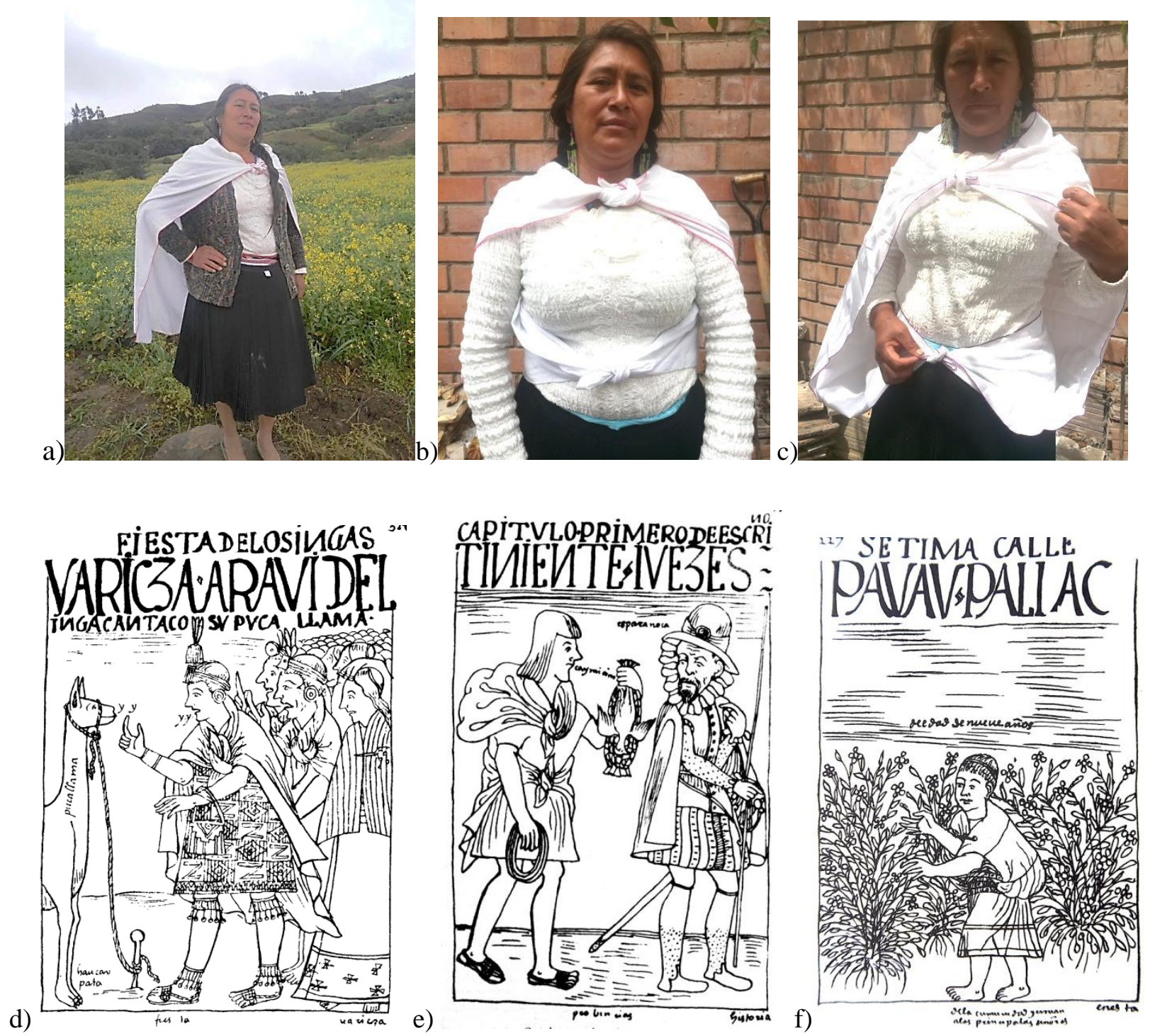

Figure 10. a) Hakun pikatash (q.), worn loose on the back by men and women for warmth. b) Hakun q'epi apyapa (q.), using two mantles to secure the bundle. c) Hakun illaguash (q.) for a light burden or personal effects. d,e,f) Details of clothing during the Inca period and the first decades of the conquest ${ }^{9}$, according to the early chronicler Guaman Poma de Ayala ${ }^{10}$.

\footnotetext{
${ }^{9}$ Figure10 d) shows us the mantle or cloak loose over the back used by the imperial nobility, as seen (left), the Inca dressed with a fine carved uncu and covered by the plain mantle, and (right) also used as a cloak by other state servants of lower rank, both loose over the shoulders and knotted.

${ }^{10}$ Guaman Poma de Ayala ms. 1615-1616 El primer nueva corónica y buen gobierno (1615/1616) (København, Det Kongelige Bibliotek, GKS $22324^{\circ}$ ) http://www5.kb.dk/permalink/2006/poma/info/en/frontpage.htm.
} 
Here we graphically collect a limited number of uses of the mantle ${ }^{11}$, for carrying and shelter, some of which have already been described by Mendizábal and Bird ${ }^{12}$, and Mendizábal ${ }^{13}$, which are here contrasted with the clothing recorded by the indigenous chronicler Guaman Poma de Ayala between 1600 and $1616^{14}$, for the Inca period and the first decades of the Spanish conquest. It is quite possible that this versatile garment had been employed from these earlier times, which significantly show similar uses to those shown here.

The custom of differentiating oneself by the garments worn on the head was noted by various chroniclers not only for its practical purposes but also as an identification of the wearer's status and ethnic group ${ }^{15}$. The use of the mantle as a headdress also shows its great versatility, which is still in use today, for shelter, protection from the wind and the sun, as well as carrying codes associated with the sphere of ritual spaces (courtship of the couple, festivities, specific signs, among others). Attention is drawn to the headdresses in Figures 1 and 2, in addition to those shown below:

a)

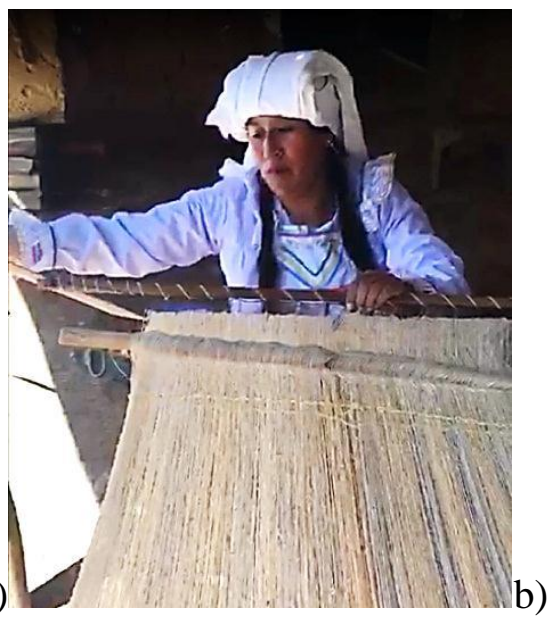

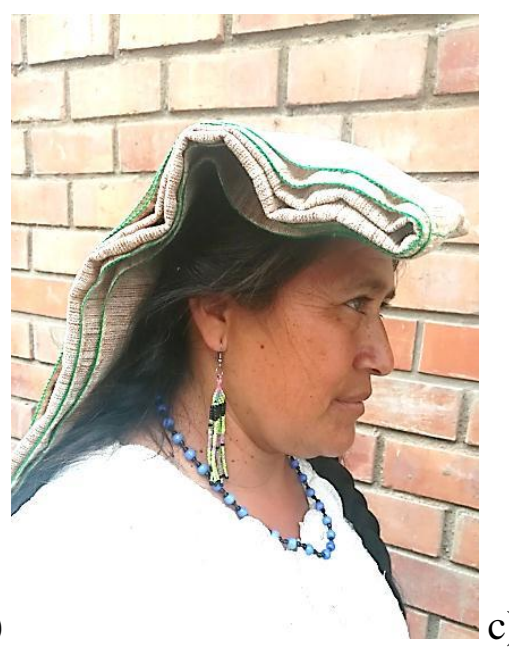

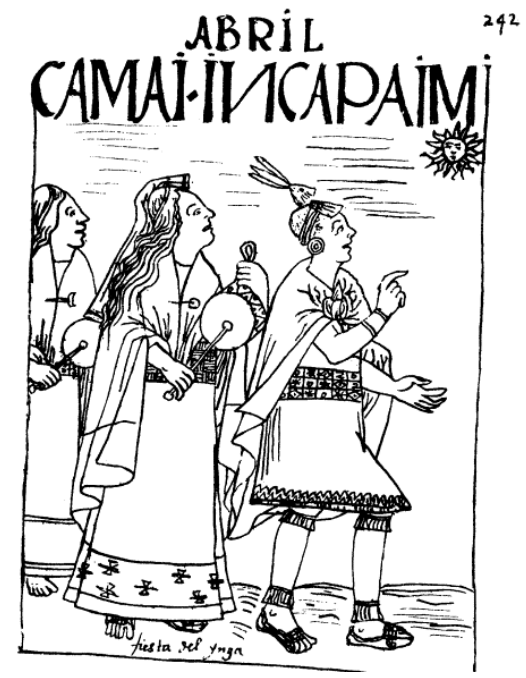

Figure 11 a) Perfect arrangement for tidying hair while at work, not previously described. b) A headdress similar to the pre-Hispanic ñañaca or pampakuna: it serves to protect from the sun. c) Inca festival in which the Coya and another elite woman play drums: she wears the nañaca (drawing Guaman Poma ms.1615-16).

The yuraq haku used by men has the same characteristics as the mantle but has a smaller range of uses, some exclusively for men, as in Figure 6, where the mantle is folded diagonally and tied at the waist to support the body during agricultural work, similar to the function of the warp belts commonly used by both men and women in rural Andean areas. Below, the pikitash (q.) and the

\footnotetext{
11 The short space does not allow us to show all the uses indicated in the images sent by Crestina Jara, so we hope to expand this information in a future publication.

12 Mendizábal y Bird, 1986.

${ }^{13}$ Mendizábal, 1990.

${ }^{14}$ Guaman Poma ms. 1615-1616.

15 ... aunque hubiese juntos cien mil hombres, fácilmente se conoscían con las señales que en las cabezas se ponian, diferenciándose cada nación en el tocado”. Pedro Cieza de León. La Crónica del Perú. 1553.
} 
scarf type, the second probably associated with longstanding cultural exchanges with mestizo people.
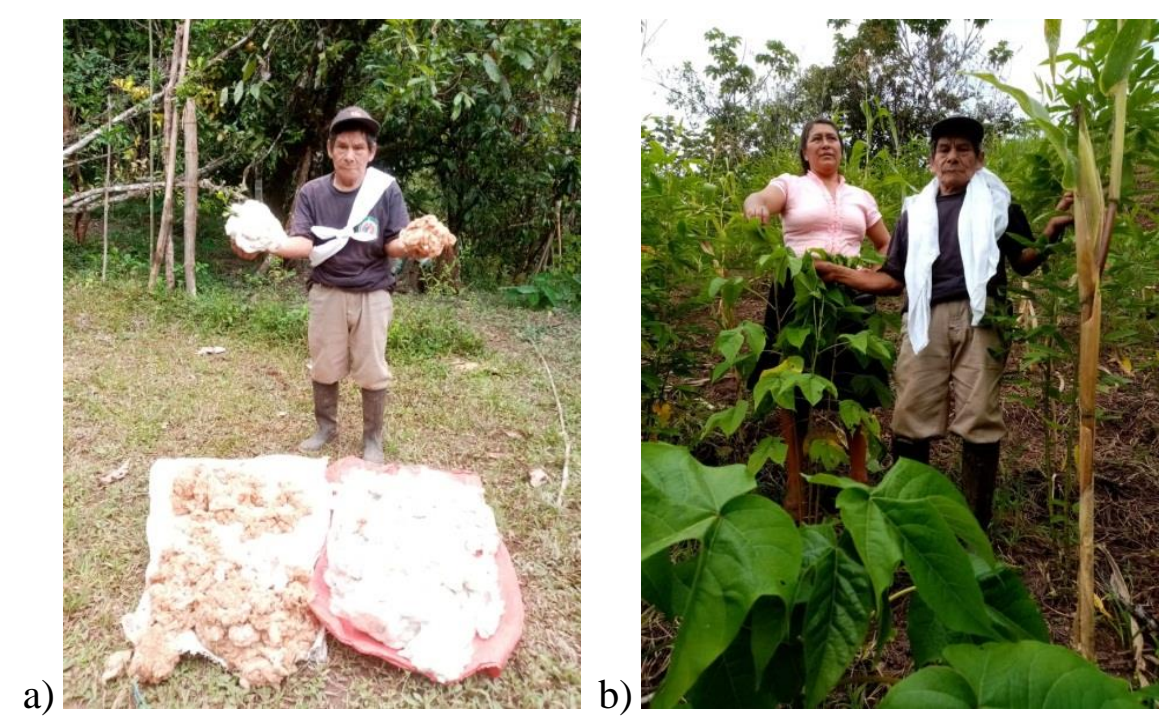

Figure 12 a) Uncle Juan Jara wears the blanket crossed with the knot in the centre, pikitash (q.) a practical use for carrying. b) Crestina Jara and her uncle, who wears the "bujanda" (scarf) type, which suggests a Spanish or Mestizo influence, for masculine use.

The techniques of folding in ethnographic textiles also offer us suggestions to consider regarding ancient traditions shared in geographically and culturally very distant spaces and the presence of mitmakuna during the Inca period (Fig. 12). Crestina Jara points out that the mantles are used following the direction of the warp, "like the backbone"; while the custom for folding and storing them follows, rather, the direction of the weft, taking care to smooth the fabric correctly, and then folding it over twice more.

a)

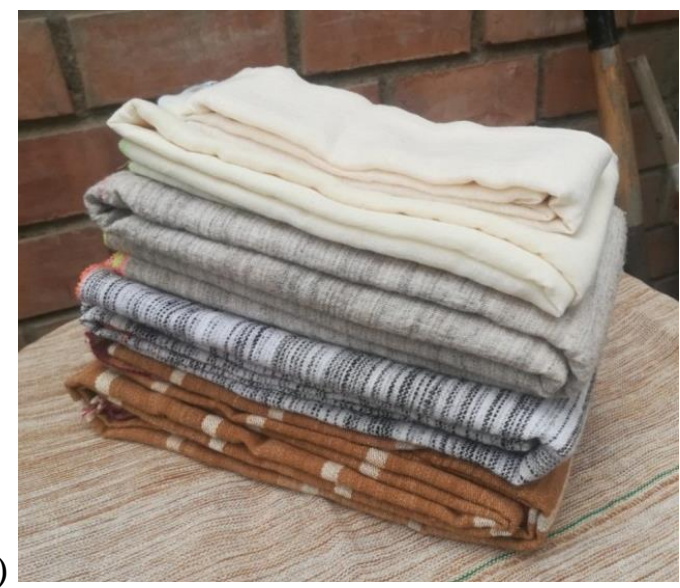

b)

Figure 12. Contemporary mantles. Before Spanish colonization, Inca mitmakuna were established here. a) Tambogán, Huánuco. b) Muyupunko, Yamparaez, near Tarabuco, in Chuquisaca, Bolivia. In: Meisch (1986) ${ }^{16}$

${ }^{16}$ Meisch, "Weaving Styles," 243-287. 
An ancient weaving tradition

In the search for long-term antecedents, a fundamental source for understanding the importance of cotton in the economy of the towns in the first decades after the Spanish conquest is La Visita de Iñigo Ortiz de Zuñiga, in 1562. ${ }^{17}$ The purpose of the Visits was to document and regulate taxes by obtaining information on the territories and their inhabitants, and also to control the excesses of Spanish officials given rights to the labor of regional populations, the Encomenderos, in the textile mills, obrajes. These inspection and census visits covered the entire population, and were carried out house by house, both to the local population and to the mitimaes or settlers transferred from Cuzco and other lands. Huánuco was among the most important centers of textile production, along with Cusco, Ayacucho and Cajamarca until the 18th century. ${ }^{18}$

Cotton was a very important local resource as a tribute currency, along with salt and coca. Its mention in La Visita is quite profuse and described in detail. Among other things, the following are noted: the origin of the cotton, whether it came from their own farms or was acquired through exchange between populations with differentiated access to the resource, especially with settlers in warm areas; ${ }^{19}$ whether it came in unspun sacks or spun into balls; the weight of the balls of cotton thread (one ounce); the quality of the yarn, fine for clothing or coarse for various uses; the quality of the fabric (fine cumbi or coarse weaves, awasqa); the standardized measurement in rods, $\operatorname{varas}^{20}$ for men's and women's clothing. The investment in labor in spinning or weaving garments, according to the same source, occupied both sexes, young and old alike.

It is expressly designated for the Quichua mitimaes caciques: Primeramente daréis vos los dichos caciques principales e indios del dicho repartimiento a vuestro encomendero cien vestidos de ropa de algodón que se entiende cada un vestido manta y camiseta y anaco y liquilla [roto] del tamaño y medida conviene a saber la manta del indio y el anaco de la india (...) un toldo y un colchón y dos tablas de manteles y veinte pañizuelos... ${ }^{21}$

In addition, the textile resource for the local economy is mentioned countless times during the visit to the Chupachu ethnic group: ...da de tributo su mujer media pieza de ropa de algodón y él está enfermo de un pie que no hace otra cosa más de tejer. Also: da de tributo media pieza de ropa de algodón y una pierna de liquilla y una gallina...; dan este indio y su mujer un anaco de algodón y catorce ovillos de hilado y no dan otra cosa. ...le daréis en cada un año tres

\footnotetext{
${ }^{17}$ Ortiz de Zúñiga, 1967.

${ }^{18}$ Catherine Julien, "Spanish Use of Inca Textile Standards," Indiana 5, 2001, 58-81. A more exhaustive review will be very important to enrich our reading of the Visita de Chucuito as it reflects practices of the textile taxation system in the southern Andean region that were being developed in Inca times.

${ }^{19}$ John Murra's study on the vertical control of a maximum of ecological floors is based on this territory and on these interethnic and economic relations. For more information see: "La Visita de los Chupachu como fuente etnológica," In Iñigo Ortiz de Zúñiga, Visita de la Provincia de León de Huanuco en 1562. Tomo I. J. Murra Editor. (Huánuco: Universidad Nacional Hermilio Valdizán, 1967).

${ }^{20}$ Old Spanish measure equivalent to $.76 \mathrm{~cm}$.

${ }^{21}$ Ortiz de Zúñiga, 1972, 281.
} 
colchones y tres toldos que sean medianos y seis tablas de manteles y sesenta pañizuelos y cuarenta y cinco ovillos de hilo de a libra todo de algodón ... ${ }^{22}$

The frequent mention of "a piece of clothing", or "a garment", or "a costume", would refer to a set of four woven garments composed of a man's blanket and shirt, and a women's anaco and liquilla (lliklla). Likewise, we understand that the mention of "one leg" would be referring to half a garment, where the garment would be composed of two halves ${ }^{23}$.

There is no doubt that the massive contribution of cotton yarn or fabrics clearly indicates access to a specialized resource in the area, particularly in terms of the climatic and environmental characteristics of the place, and particularly is differentiated from the resources available in other more frigid areas of the Andes, such as camelid fibers. It is possible that the tribute in balls of yarn went directly to the encomenderos' mills to be transformed into products as payment for services or for sale in the market.

The frequent mentions of cumbicos or cumbicamayos villages ${ }^{24}$ would indicate the existence of a population of settlers or settlers transferred from other areas of the empire, in this case weavers specialized in the manufacture of high-quality garments, or clothing of cumbi cloth. These were destined for people of the Inca elite and continued with a category of privilege extended to the Spanish ruling class, specifically differentiated in La Visita from the weavings in plain cotton cloth, for the purposes of tribute..$^{25}$

The presence of specialized weavers from other areas for the production of fine weavings is also supported by the design of the narrow belt woven on a backstrap loom, now used to tie skirts, recorded by Crestina Jara (Fig. 13). This is similar in design to the sara chumbe (q.), a belt worn by the Coyas (female Inca rulers) during the corn festivals, documented by the chronicler Martín de Murúa ${ }^{26}$ and the subject of subsequent enlightening studies in San Ignacio de Loyola, in the highlands of the coastal department of La Libertad ${ }^{27}$ (Fig. 14).

\footnotetext{
22 Ortiz de Zúñiga, 1967, 165, 256, 263, 306, 313.

${ }^{23}$ At present, a mantle of quadrangular format is made up of two pieces joined together, each with four selvedges, called callu (q.). This is valid for the entire Andean area of Peru.

${ }^{24}$ Ortiz de Zúñiga, 1967, 92-94-300-306-308.

${ }^{25}$ Miguel León., Paños e hidalguía. Encomenderos y sociedadcolonial en Huánuco, (Lima: Instituto de Estudios Peruanos, 2002). It is noted that according to the tax rate, the natives of Huánuco were obliged to hand over abasca (common) and cumbi clothes, but the encomenderos obliged them to pay taxes only on the cumbi clothes, which had a higher market value.

${ }^{26}$ For detailed information: Sophie Desrosiers, “An interpretation of Technical Weaving Data Found in an Early $17^{\text {th }}$-Century Chronicle," In The Junius B. Bird Conference on Andean Textiles, Ann P. Rowe, Editor. (Washington DC: The Textile Museum, 1986), 219-241.

${ }^{27}$ Arabel Fernández, "Fajas sara y pata de San Ignacio de Loyola, Patrimonio Cultural del Perú," In Patrimonio del Perú. Humanidad Andina, C. Galvez y A. Rocchietti (Comp). (Córdoba: Editorial Universitaria Villa María Dirección Regional de Cultura, La Libertad, 2014). Lynn Meisch, "Fajas sara: Supervivencia de una tradición textil inca en el norte del Perú," In La Trama y la Urdimbre. Textiles tradicionales del Perú, (Lima: Universidad Ricardo Palma - Instituto Cultural Peruano Norteamericano, 2007).
} 
The chronicler's record of the procedure warns of the importance of this garment and, in particular, of the importance of following a precise pattern for its manufacture. This simple garment would be indicative of the mark left by the presence of Inca mitimaes in the area, contributing to extend the area of distribution of this design to the region of Huánuco as noted in present time. The argument reinforces the importance of the sara chumbe associated with corn festivals, whose notation was diligently recorded by the chronicler in his writings.

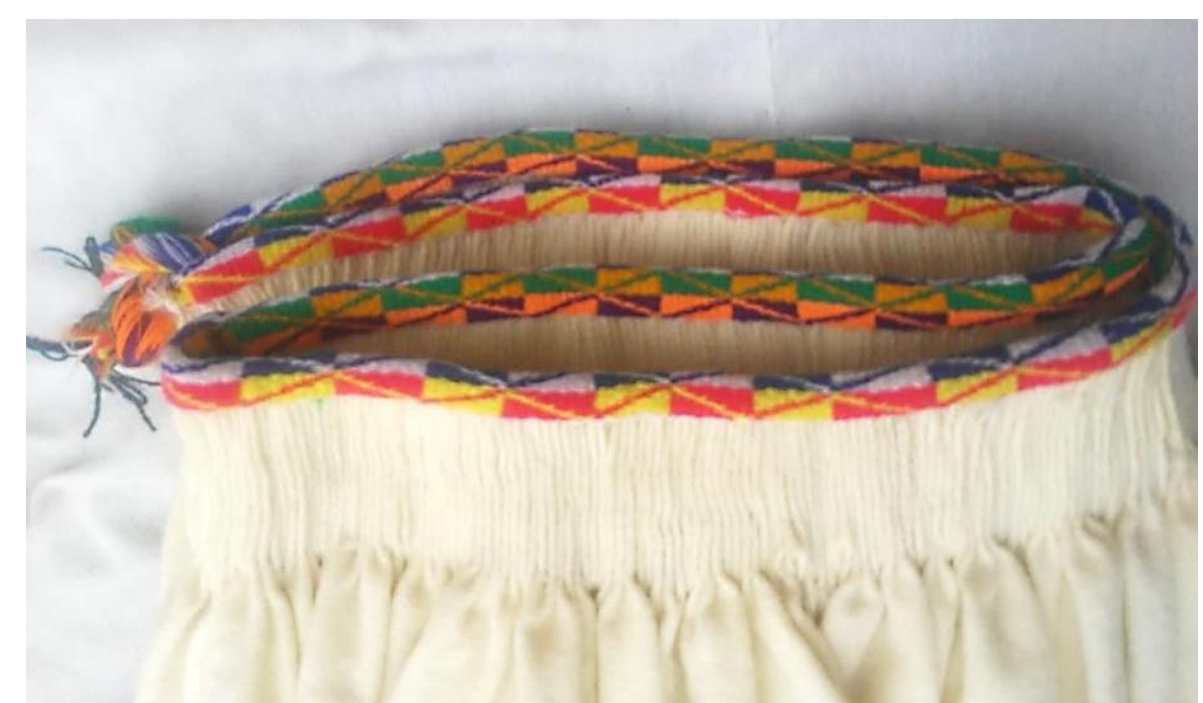

Figure 13. Band woven on a backstrap loom in sheep's wool, that binds the waistband of a skirt. Used today in the areas of Panao and Churubamba, Huánuco.

a)

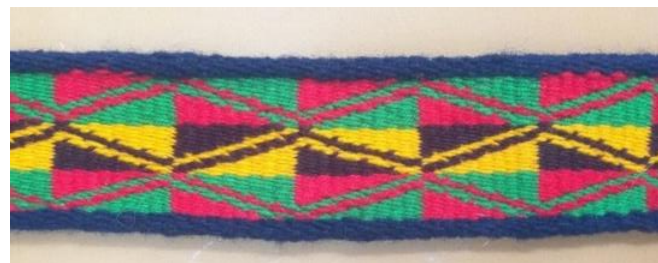

b)

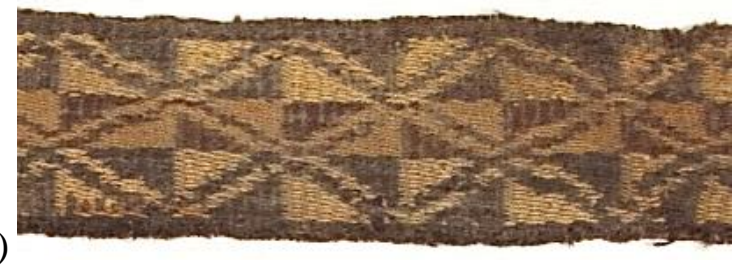

c)

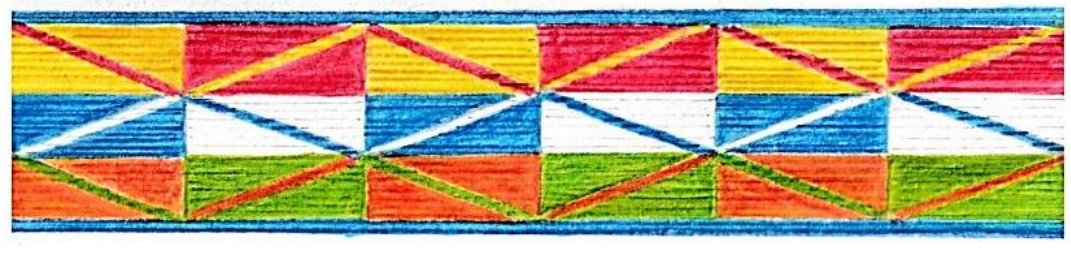

Figure 14. a) Contemporary sara belt. San Ignacio de Loyola, La Libertad. b) Prehispanic Inca style belt from unknown context. Alpaca fiber. ${ }^{28}$

c) Contemporary belt from the area of Panao, Huánuco.

Drawing by Nora Carrasco.

${ }^{28}$ Desrosiers 1986. Photo: Courtesy of the Division of Anthropology, AMNH. Catalog No: B/4642. 


\section{To conclude}

Therefore, we can see that there are several indications that point to the importance of textile production over the long term in the territory of Huánuco. How historical and contemporary textiles become precious documents containing information that allow us to connect the past and the present, and offer us arguments to take into account that would explain the richness of an ancient and important tradition of cotton weavers. I believe that contributing to their dissemination is fundamental for the empowerment and strengthening of individuals and communities currently involved in weaving, in favor of the safeguarding of their cultural heritage.

The weaver Crestina Jara, adding the story of her experience, becomes a collective voice and memory, and forms part of this important tradition of cotton weavers. She has shown us through her voluntary participation in this endeavor the importance of staying connected, of building links and cementing relationships that can eventually manifest themselves in other spheres of life, through the emotion she puts into caring for the teachings received from her elders, and open to new expectations for the future.

Today, the weaving community is initiating an experience with new markets, giving a new meaning to the mantle, now assumed as a symbol of identity towards the outside world and, at the same time, a device that contributes to the satisfaction of their needs, both material and spiritual, from the space they know best: their cultural heritage as a fundamental source and resource.

\section{Acknowledgements}

To Crestina Jara, master spinner and weaver from Huanuco, for her great collaboration in this project, without whom this article would not have been written. The support and generosity of Ann Peters in organizing the session "Dialogues between archaeological, historical and contemporary textiles in the Andes", facilitating the participation of our "Saturday" group and supporting our workshop dynamics, as well as in the editing process, deserves special recognition, as do the colleagues of the group, Verónica, Soledad, Yuki, Bárbara and Rommel, for their accompaniment in difficult moments. To Sophie Desrosiers for her reading and wise comments during the process of the study. To TSA, an essential event, thank you for continuing in your organizational efforts. 


\section{Bibliography}

Bird, Robert McKelvy and Emilio Mendizábal L. "Textiles, Weaving, and Ethnic Groups of Highland Huanuco, Peru." In The Junius B. Bird Conference On Andean Textiles. A.P. Rowe Editor. Washington, D.C.: The Textile Museum, 1986, 339-361.

Desrosiers, Sophie. "An interpretation of Technical Weaving Data Found in an Early $17^{\text {th }}$ Century Chronicle." In The Junius B. Bird Conference on Andean Textiles. Ann P. Rowe, Editor. Washington DC: The Textile Museum, 1986, 219-241.

Emilio, Mendizábal L. Continuidad Cultural y Textilaria en Pachitea Andina. Lima: Tarea, 1990.

Fernández, Arabel. "Fajas sara y pata de San Ignacio de Loyola, Patrimonio Cultural del Perú." In Patrimonio del Perú. Humanidad Andina. C. Galvez y A. Rocchietti (Comp). Córdoba: Editorial Universitaria Villa María - Dirección Regional de Cultura, La Libertad, 2014.

Julien, Catherine. "Spanish Use of Inca Textile Standards.” Indiana 5, 2001, 58-81.

León, Miguel. Paños e hidalguía. Encomenderos y sociedadcolonial en Huánuco. Lima: Instituto de Estudios Peruanos, 2002.

Meisch, Lynn A. "Weaving Styles in Tarabuco, Bolivia." In The Junius B. Bird Conference On Andean Textiles. A.P. Rowe Editor. Washington, D.C.: The Textile Museum, 1986, 243-287.

Meisch, Lynn. "Fajas sara: Supervivencia de una tradición textil inca en el norte del Perú." In $L a$ Trama y la Urdimbre. Textiles tradicionales del Perú. Lima: Universidad Ricardo Palma Instituto Cultural Peruano Norteamericano, 2007.

Ortiz de Zúñiga, Iñigo. Visita de la Provincia de Leon de Huanuco en 1562. Tomo I. J. Murra Editor. Huánuco: Universidad Nacional Hermilio Valdizán, 1967. And Tomo II. J.Murra Editor. Huánuco: Universidad Nacional Hermilio Valdizán, 1972.

Splitstoser, J. C., T. D. Dillehay, J. Wouters, and A. Claro. "Early pre-Hispanic use of indigo blue in Peru." Science Advances (14 Sep 2016): Vol. 2, no. 9, e1501623 DOI:

10.1126/sciadv.1501623.

"La Visita de los Chupachu como fuente etnológica." In Iñigo Ortiz de Zúñiga. Visita de la Provincia de León de Huanuco en 1562. Tomo I. J. Murra Editor. Huánuco: Universidad Nacional Hermilio Valdizán, 1967. 
Guaman Poma de Ayala ms. 1615-1616 El primer nueva corónica y buen gobierno (1615/1616) (København, Det Kongelige Bibliotek, GKS $22324^{\circ}$ )

http://www5.kb.dk/permalink/2006/poma/info/en/frontpage.htm. 